\title{
Pemecahan Masalah Dengan Pendekatan Saintifik Dan Koperatif Tipe Nht, Serta Peningkatan Kemampuan Komunikasi Matematika Siswa SMP
}

\author{
Valeria Suryani Kurnila ${ }^{1}$, Maria Anita $\mathrm{Jau}^{2}$, Sebastianus Fedi ${ }^{3}$, \\ Yohanes Kurniawan ${ }^{4}$ \\ 1,2,3,4 Pendidikan Matematika STKIP Santu Paulus Ruteng, NTT
}

\begin{abstract}
This study aims to determine the difference of the mathematical communication skills improvement of students who obtained mathematical learning by problem-solving of scientific approach and Number Head Together (NHT) of cooperative learning and the students who obtained mathematical learning through the use of problem-solving approach only. This research is a quasi-experimental study with nonequivalent control group design. The population of this study was 274 students of $8^{\text {th }}$-grade who were distributed to seven classes. The samples taken were two classes, each of which consisted of 41 students for the experimental class and 42 students for the control class. The data were analyzed to compare students' mathematical communication skills using descriptive statistics and inferential statistics ttest. The result of this research showed that the mathematical communication skills improvement through the application of problem-solving of scientific approach and NHT of cooperative learning was higher than the mathematical communication skills of students who used a problem-solving approach only.
\end{abstract}

Keywords: Problem-solving; Number Head Together; Mathematical Communication Skills

\section{PENDAHULUAN}

Matematika dalam pembelajarannya dapat dilakukan dengan proses problem possing dan problem solving (Ali: 2007). Ketika siswa mempelajari matematika, pada dasarnya terdiri dari dua hal penting yaitu dihadapkan pada sejumlah fakta (masalah) dan bagaimana menyelesaikan masalah tersebut. Hal ini menunjukkan bahwa matematika bukan hanya sekedar aritmatika, namun sebuah aktivitas. Pembentukan aktivitas tersebut dapat dilaksanakan dalam pembelajaran matematika. Hal ini sejalan dengan Permendiknas Nomor 22 Tahun 2006 menyatakan bahwa pemberian mata pelajaran matematika agar siswa memiliki kemampuan memecahkan masalah yang meliputi kemampuan memahami masalah, merancang model matematika, menyelesaikan model dan menafsirkan solusi yang diperoleh, serta mengkomunikasikan gagasan dengan simbol, tabel, diagram, atau media lain untuk memperjelas keadaan atau masalah. Oleh 
karena itu, pembelajaran matematika harus berdasarkan penguasaan konsep, keterkaitan antar konsep, serta memiliki kemampuan algoritmik yang baik. Ketiga hal ini memberikan dampak yang baik bagi siswa dalam proses memecahkan masalah maupun mengkomunikasikan gagasan secara matematis.

Kemampuan komunikasi matematika merupakan kekuatan sentral bagi siswa dalam merumuskan konsep dan strategi, serta modal bagi siswa dalam melakukan eksplorasi dan investigasi matematika (Izzati \& Suryadi, 2010). Siswa diharapkan memiliki konsep matematika yang benar dan menggunakannya secara tepat dalam pembelajaran maupun kehidupan sehari-hari. Susanto (2013) juga menambahkan bahwa kemampuan komunikasi adalah kemampuan mengekspresikan ide-ide matematika secara lisan dan tulisan. Siswa harus mampu mengungkapkan gagasan matematis secara tertulis menggunakan pendekatan bahasa matematika (notasi, istilah, dan lambang) serta menggunakan representasi matematika (rumus, diagram, tabel, grafik, model) untuk menyatakan informasi matematis (Izzati \& Suryadi, 2010). Oleh karena itu pembelajaran matematika harus menjadi proses komunikasi, yaitu proses penyampaian pesan dari sumber pesan melalui media atau cara tertentu ke penerima pesan (Sadiman, 2012).

Hasil pengamatan pembelajaran di SMP Negeri 7 Ruteng, menunjukkan bahwa kemampuan komunikasi matematika siswa dalam pembelajaran matematika masih terhitung rendah. Hal ini ditunjukkan oleh 43,3\% siswa belum mencapai kriteria ketuntasan minimal pada ujian akhir semester. Hal ini tampak terlihat pada sebagian besar siswa tidak menyelesaikan soal dengan benar karena beberapa hal antara lain, siswa belum memahami soal secara baik sehingga siswa menggunakan rumus yang salah dalam menyelesaikan soal. Selain itu, ada pula yang sudah tepat menilih rumus yang akan digunakan dalam penyelesaian soal, namun tidak tepat menghubungkan apa yang diketahui dengan simbol-simbol pada rumus, sehingga penyelesaian soal pun tidak tepat. Ketidaktepatan tersebut juga disebabkan oleh tidak terbiasanya siswa dengan soal-soal non rutin atau masalah matematika. Soal yang biasa diberikan kepada siswa masih bersifat rutin. Guru masih berangggapan bahwa masalah matematika yang disajikan dalam pembelajaran hanya berupa soal rutin. Guru beranggapan konteks soal beragam tidaklah terlalu penting untuk diperhatikan, asalkan siswa mengikuti langkah-langkah memecahkan masalah. Sehingga siswa memiliki kecenderungan untuk bekerja dan berpikir berdasarkan dari apa yang disampaikan oleh guru saja. Belum nampak siswa 
kreatif menemukan sesuatu dalam proses pembelajaran. Ketika proses pembelajaran pun, sebagian besar siswa memilih untuk diam dan tidak ikut aktif dalam pembelajaran, karena siswa memiliki kekhawatiran diberi pertanyaan oleh guru. Masalah tersebut tidak boleh dibiarkan, karena apabila hal tersebut dibiarkan maka pembelajaran matematika tidak dapat berjalan seperti yang diharapkan.

Pendekatan pemecahan masalah merupakan komponen yang sangat penting dalam matematika. Pemecahan masalah adalah proses menerapkan pengetahuan yang telah diperoleh siswa sebelumnya ke dalam situasi yang baru, yang berdampak pada peningkatan kemampuan komunikasi matematika siswa (Susanto, 2013). Hasil penelitian Komara (2015) menunjukkan bahwa tahap-tahap pemecahan masalah mendorong siswa menemukan masalah, mengelaborasi deangan berbagai dugaan, serta mengeksplorasi alternatis penyelesaian, Hal ini mendorong siswa mengkomunikasikan ide matematisnya ke dalam simbol, gambar ataupun penjelasan logis. Akan tetapi hal ini bisa terjadi dengan memberikan siswa sebuah masalah, bukan hanya sekedar soal rutin seperti yang terjadi di tempat penelitian ini dilakukan. Pemecahan masalah yang diterapkan pun hanya terbatas pada langkah-langkah menyelesaikan soal rutin pada proses pembelajaran. Siswa tidak dilatih untuk menggali secara mendalam bagaimana mengaplikasikan rumus dengan beberapa konsep soal yang berbeda. Sehinggga kemampuan komunikasi matematika siswa terkait notasi, istilah, lambang, rumus, diagram, tabel, grafik, model matematika serta penerapannya menjadi terbatas. Selain itu, siswa memiliki kemampuan berpikir yang berbeda-beda, sehingga proses penyelesaian masalah pun pasti berbeda-beda dan kecepatan penyelesaiannya pun berbeda. Pendekatan pemecahan masalah memungkinkan siswa cenderung untuk menyelesaikan sendiri. Siswa memiliki kecenderungan untuk bersikap individualistis dalam menyelesaikan soal. Hal ini menyebabkan pada akhirnya terjadi perbedaan yang mencolok pada kemampuan komunikasi matematika siswa.

Permendikbud Nomor 65 Tahun 2013 menjelaskan bahwa pengetahuan bisa diperoleh melalui aktivitas "mengingat, memahami, menerapkan, menganalisis, mengevaluasi dan mencipta”. Namun hal tersebut harus didukung oleh keterampilan yang diperoleh melalui aktivitas "mengamati, menanya, mencoba, menalar, menyaji dan mencipta”. Aktivitas keterampilan tersebut merupakan langkah-langkah saintifik. Langkah-langkah tersebut digunakan agar siswa menjadi lebih produktif, kreatif, inovatif dan afektif. Pendidik dan tenaga kependidikan menjadi lebih bergairah dalam mengajar 
dan memiliki kompetensi profesional, pedagogik, kepribadian dan sosial yang harus dikembangkan. Menurut Musfiqon dan Nurdyansyah (2015), kelima langkah-langkah saintifik bisa dilakukan secara berurutan atau pun tidak berurutan. Hal ini dilakukan pada langkah pertama dan kedua. Sedangkan pada langkah ketiga sampai kelima sebaiknya dilakukan secara terurut. Langkah-langkah tersebut memberikan kesempatan bagi siswa untuk membangun kemandiriannya serta mengoptimalkan kecerdasannya. Langkahlangkah terstruktur itu pun semakin bermakna ketika dikolaborasikan dengan langkahlangkah pemecahan masalah. Saat itu siswa akan terus berlatih dalam melakukan penyelidikan terhadap kebenaran matematika (Sriraman \& English, 2010). Selain itu, akan muncul memiliki rasa ingin tahu, perhatian, dan minat dalam mempelajari matematika, serta sikap ulet dan percaya diri dalam pemecahan masalah (Yuwono, 2014).

Agar penyelidikan berjalan baik, maka siswa perlu mendapatkan informasi dari teman yang lain. Informasi tersebut adalah hasil diskusi yang dilakukan dengan seksama, karena akan dipresentasikan sebagai poin kemenangan kelompok. Sehingga pemecahan masalah dengan pendekatan saintifik perlu juga dikolaborasi dengan salah satu pembelajaran koperatif yaitu tipe Number Head Together (NHT). Tipe tersebut bisa memberikan kesempatan yang sama bagi siswa menyelesaikan soal, saling berbagi ide antara siswa dalam diskusi sehingga bisa mempertimbangkan bersama solusi dari soal yang diberikan (Huda, 2013). Hasil penelitian Miftahurrohman \& Purnomo (2017) menunjukkan penerapan NHT melatih siswa untuk saling mendengarkan informasi dengan cermat, saling berbagi informasi, serta berbicara dengan penuh perhitungan, hal ini membuat siswa lebih aktif serta produktif dalam pembelajaran matematika.

Kolaborasi ketiga hal tersebut dapat menciptakan situasi baru yang kondusif bagi siswa, sebagai standar proses yang harus dilaksanakan sesuai Kurikulum 2013. Hal tersebut tentu akan melatih siswa secara terus menerus mengungkapkan gagasan matematis menggunakan notasi, istilah dan lambang. Selain itu, siswa juga akan dilatih untuk menggunakan rumus, diagram, tabel, grafik, model untuk menyatakan informasi matematis.

\section{METODE PENELITIAN}

Penelitian ini menggunakan pendekatan quasi ekperimental dengan desain Nonequivalent Control Group Design. Rancangan ini dipilih karena selama penelitian 
tidak memungkinkan untuk mengubah kelas yang telah ada (Sugiyono, 2012). Pada kelompok tersebut diberikan pretes dan postes. Pretes digunakan untuk melihat kemampuan komunikasi matematika sebelum diberikan perlakuan. Sedangkan, postes digunakan untuk melihat kemampuan komunikasi matematika setelah diberikan perlakuan. Peningkatan kemampuan komunikasi matematika siswa dihitung dengan rumus gain skor ternormalisasi.

Penelitian ini menggunakan menggunakan dua kelompok yakni kelompok eksperimen dan kelompok kontrol. Populasi dalam penelitian ini adalah siswa kelas VIII SMP Negeri 7 Ruteng-Cumbi dengan jumlah 274 yang menempati 7 kelas. Pengambilan sampel dalam penelitian ini dilakukan dengan teknik nonrandom sampling. Dari populasi yang ada diambil dua kelas yang masing-masing berjumlah 41 orang siswa untuk kelas eksperimen dan 42 orang siswa untuk kelas kontrol.

Pembelajaran yang dilakukan pada kelas eksperimen menggunakan pemecahan masalah dengan pendekatan saintifik dalam setting kooperatif NHT. Sedangkan pada kelas kontrol, pembelajaran yang digunakan adalah pembelajaran konvensional, yaitu menggunakan pendekatan pemecahan masalah, Data kemampuan komunikasi dikumpulkan dengan menggunakan tes uraian. Instrumen tes kemampuan komunikasi matematika dinyatakan valid pada analisis uji validitas dan reliabel cukup tinggi pada analisis uji reliabilitas instrumen. Sehingga menghasilkan instrumen pretes dan postes berupa soal uraian yang terdiri dari 1 soal kategori mudah, 1 soal kategori sedang dan 1 soal kategori sulit. Ringkasan hasil analisis uji reliabilitas instrumen tes komunikasi matematika disajikan pada Tabel 1.

Tabel 1. Uji reliabilitas instrumen pretes dan postes

\begin{tabular}{cccc}
\hline Instrumen Tes & $\mathbf{r}_{11}$ & $\mathbf{r}_{\text {tabel }}$ & Keterangan \\
\hline Pretes & 0,707 & 0.3061 & Reliabel cukup tinggi \\
Postes & 0,752 & 0.3061 & Reliabel cukup tinggi \\
\hline
\end{tabular}

Uji statistik untuk membandingkan peningkatan kemampuan komunikasi matematika siswa pada kelas eksperimen dan kelas kontrol, menggunakan statistik deskriptif dan statistik inferensial uji-t. 


\section{HASIL DAN PEMBAHASAN}

Pembelajaran pada kelas eksperimen yang menggunakan pemecahan masalah dengan pendekatan saintifik dalam setting kooperatif NHT sebagai berikut: Pertama, kegiatan mengamati. Sebelum melakukan kegiatan tersebut, guru membagi siswa ke dalam 8 kelompok dan setiap siswa dalam kelompok diberi identitas berupa nomor. Setelah itu, guru menyajikan sebuah masalah yang tercantum dalam lembar kerja kelompok dan siswa mulai mengamati masalah tersebut. Saat kegiatan tersebut berjalan, guru juga memberikan pertanyaan-pertanyaan berupa "Apakah ada kata yang tidak dipahami pada masalah?”, “Apakah kamu sudah pernah mengalami masalah ini juga?","Pernahkah kamu melihat ini sebelumnya”, “Apakah kamu tahu tujuan kita mengamati masalah ini?”, serta “Adakah simbol matematika di dalamnya?”. Pertanyaanpertanyaan tersebut menuntun siswa untuk berdiskusi, melihat gambar pada masalah, menyimak pembicaraan teman lain, bahkan terjadi selisih paham antar siswa, namun tidak sampai menimbulkan kegaduhan. Hal ini terjadi karena satu kelompok ditempati oleh siswa dengan beragan kemampuan. Para siswa berusaha untuk menyampaikan pendapatnya. Hal ini sejalan dengan penelitian Susanto dan Bharata (2018) yang menemukan bahwa menempatkan siswa lain sebagai pesaing utama dalam proses pembelajaran, mampu meningkatkan semangat kompetitif dan belajar yang tinggi bagi siswa lain.

Kedua, kegiatan menanya. Pada proses ini terlihat bahwa siswa sangat antusias memikirkan berbagai pertanyaan kepada guru. Siswa diperbolehkan menanyakan simbol, rumus, gambar atau apapun terkait masalah yang diberikan. Agar pertanyaan yang diberikan siswa rasional, guru memberikan pertanyaan penuntun terlebih dahulu. Pertanyaan tersebut dijawab setelah terjadi diskusi antara siswa dalam satu kelompok. Jawabanpun bisa diperbaiki oleh anggota kelompok lain jika salah. Siswa memberikan jawaban sangat beragam dan pertanyaan yang sangat beragam pula, sesuai dengan cara berpikirnya. Hal ini sejalan dengan hasil kajian dari Kurnila (Kurnila, 2013), yang menyatakan bahwa langkah yang dipikirkan oleh siswa bisa beragam. Hal ini bergantung pada budaya atau kebiasaan masing-masing siswa. Pada tahap ini juga, siswa sudah mulai melakukan investigasi dengan menulis dugaanya menyelesaikan masalah yang diberikan. Dugaannya pun beragam. Siswa menyatakan solusi masalah dengan gambar, tabel, rumus, serta menggunakan prosedur aljabar atau aritmetik. Menurut Pehkonen, Näveri, 
dan Laine (2013), pada saat kegiatan investigasi dalam proses memecahkan masalah, siswa mempromosikan kreativitas yang dimilikinya. Hal ini tentunya berdampak pada dugaan penyelesaian yang dibuat siswa.

Ketiga, mengumpulkan informasi. Pada proses ini siswa menggunakan berbagai sumber belajar. Sumber belajar yang dimanfaatkan adalah buku-buku dari perpustakaan, majalah, serta lingkungan yang ada di sekitar. Misalnya, atap rumah Gendang sebagai rumah adat, yang disebutkan dalam soal. Untuk lebih meyakinkan penyelesaiannya, maka (Komara, 2015)beberapa siswa mengamati secara langsung bentuk bangunan tersebut, yang lokasinya di samping sekolah. Selain melakukan proses pengamatan, para siswa berdiskusi untuk mengumpulkan berbagai hal dalam menjawabi masalah dan hal-hal baru terkait dengan masalah yang diberikan. Pada saat berdikusi terlihat bahwa ada siswa yang masih memiilki pengetahuan matematika yang minim, misalnya perbedaan antara pengunaan diameter dan jari-jari dalam luas lingkaran. Selain itu kecenderungan siswa hanya menggunakan nilai $\pi=3,14$, tanpa memperhatikan bilangan yang dikali atau dibagi dengan $\pi$ adalah bilangan yang habis dibagi 7. Padahal perhitungan akan lebih mudah ketika menggunakan nilai $\pi=22 / 7$. Namun dengan bantuan siswa lain dalam kelompok, hal tersebut menjadi teratasi. Hal ini terjadi karena adanya proses diskusi yang meyakinkan tiap anggota dalam kelompokya agar mengetahui dan memahami sumber informasi yang diperoleh oleh kelompok tersebut. Hal tersebut poin penting sebagai akibat dari penerapan NHT yang menekankan sistem simbiosis mutualisme anggota kelompok dalam menyampaikan gagasannya, sehingga mampu meningkatkan kemampuan siswa mengenal fakta, konsep ataupun prinsip matematika (Rahmalia, Armiati, \& Jazwinarti, 2012).

Keempat, menalar atau mengasosiasi. Pada tahap ini, siswa menyusun dan menerapkan strategi yang tepat untuk menyelesaikan masalah.Hal ini sebagai salah satu langkah memecahkan masalah. Siswa menyusun strategi dengan memanfaatkan informasi yang telah mereka kumpulkan pada tahap sebelumnya. Saat menentukan strategi dan menggunakannya dalam penyelesaian masalah, terlihat bahwa ada kelompok siswa yang memiliki satu pemikiran terkait strategi yang digunakan. Namun ada pula yang harus melalui perdebatan terlebih dahulu, karena beragamnya strategi yang ditawarkan anggota dalam kelompoknya. Pada tahap ini pula ditemukan bahwa saat strategi pertama tidak mampu menyelesaikan masalah, maka para siswa sangat 
bersemangat untuk mencari strategi lain. Hal ini terjadi karena akan ada proses mengkomunikasikan strategi dan penggunaannya menyelesaikan masalah pada tahap berikutnya. Doer dan Lerman (2010) juga menyatakan bahwa para siswa harus bisa menyediakan deskripsi, penjelasan dan pembenaran tentang tugasnya secara lisan dan tertulis. Hal ini menjadi tantangan baru bagi guru untuk belajar lebih banyak hal, sehingga mendukung pengembangan kemampuan komunikasi secara matematis. Pada tahap ini pula, siswa juga menemukan pola untuk menyelesaikan persoalan lain serupa dengan masalah yang disajikan. Pola yang dibuat oleh siswa adalah langkah-langkah penyelesaian dan mendefinisikan setiap langkah-langkah tersebut. Pola itu dibuat berdasarkan pemahaman mereka. Sehingga dalam pembelajaran ditemukan pola yang sama, namun dengan langkah-langkah dan pendefinisiannya yang berbeda. Guru juga berperan dalam kegiatan mengasosiasi. Guru mencek dan mengontrol langkah-langkah penyelesaian yang dibuat oleh kelompok siswa. Hal ini menyebabkan setiap kelompok siswa memiliki langkah yang efektif dan efisien.

Kelima, mengkomunikasikan. Proses ini dilakukan dengan menerapkan langkah NHT, yaitu guru hanya menunjuk siswa tertentu dari kelompoknya. Guru melakukannya dengan menyebutkan nomor tertentu. Sehingga pada tahap ini, beberapa siswa terlihat agak gugup. Mereka merasa bertanggung jawab terhadap keberhasilan kelompoknya. Pada saat mempresentasikan hasil penyelesaian masalah, terdapat beberapa cara yang digunakan siswa untuk menyampaikan hasil. Ada yang menggunakan karton sebagai media, dengan mencantumkan alur-alur penyelesaian dengan menggunakan bagan. Ada pula yang membuat gambar terlebih dahulu di papan tulis untuk menyampaikan ide mereka. Gambar yang dibuat pun menarik dan menggambarkan cerita pada masalah dan proses penyelesaiannya. Ada juga yang membuat demonstrasi singkat dengan menggunakan peralatan sederhana, sambil dijelaskan oleh siswa yang telah ditunjuk oleh guru, sehingga menimbulkan pembelajaran yang interaktif antar siswa dengan kemampuan dan latar belakang yang berbeda. Hal ini tergambar dari perubahan sikap yang ditunjukkan oleh beberapa siswa yaitu lebih terlihat percaya diri dari biasanya. Selain itu, siswa diberi kesempatan untuk menyampaikan idenya sesuai pemahamannya sebagai cara untuk mengkomunikasikan wawasan matematika yang dimilikinya. Hal ini sejalan dengan penelitian yang dilakukan Tinungki (2015), yaitu pengembangan kemampuan komunikasi matematika membawa dampak baik terhadap penalarannya dan 
pengilustrasian ide matematika ke dalam model matematika. Siswa pun diberi kesempatan untuk menghubungkan berbagai proses ke konsep matematika, maupun ke konsep ilmu-ilmu lain. Setelah siswa dari masing-masing kelompok menyajikan penyelesaian masalahnya, selanjutnya guru dan kelompok lain memberikan masukan. Guru paling banyak memberi masukan bagi semua kelompok, terutama pada langkahlangkah ataupun penggunaan simbol, gambar, grafik, aljabar serta bahasa yang digunakan. Setelah kegiatan presentasi dilakukan, selanjutnya guru memberikan kuis yang dikerjakan oleh masing-masing siswa. Hal ini dilakukan agar guru juga mengetahui kemampuan komunikasinya secara tertulis, serta membandingkannya dengan kemampuan secara lisan yang telah dilakukan saat pembelajaran berlangsung.

Kolaborasi pemecahan masalah dengan pendekatan santifik dan NHT memberikan suasana pembelajaran yang baru dan menarik bagi siswa. Proses menggali informasi menjadi lebih terarah dan lebih mendalam..Sehingga mereka mampu mengungkapkan gagasan matematis dengan menggunakan notasi, istilah dan lambang serta mampu menggunakan rumus, diagram, tabel, grafik, model untuk menyatakan informasi matematis. Dialog yang terjadi antara siswa dengan siswa lain menjadi lebih intens, sehingga bahasa matematika dan representasi matematika yang dimiliki siswa pun bertambah.

Data hasil penelitian yang digunakan dalam penelitian ini adalah data pretes dan postes. Data hasil tes tersebut untuk mengukur kemampuan komunikasi matematika siswa pada kelas eksperimen dan kelas kontrol seperti pada Tabel 2 berikut ini:

Tabel 2. Deskripsi Data Pretes-Postes Kelas Ekperimen (E) dan Kelas Kontrol (K)

\begin{tabular}{ccccc}
\hline \multirow{2}{*}{ Nilai Statistik } & \multicolumn{2}{c}{ Kelas E } & \multicolumn{2}{c}{ Kelas K } \\
\cline { 2 - 5 } & Pretes & Postes & Pretes & Postes \\
\hline Maks & 48 & 92 & 43 & 77 \\
Min & 10 & 66 & 10 & 38 \\
Rata-rata & 26.2 & 77.9 & 23. & 58.5 \\
V & 85.4 & 59.9 & 87.4 & 96.8 \\
SD & 9.2 & 7.8 & 9.3 & 9.8 \\
\hline
\end{tabular}

Data Pretes-Postes kelas eksperimen dan kelas kontrol.menunjukkan bahwa hasil pretes pada kelas eksperimen dengan nilai tertinggi 48, nilai terendah 10, rata-rata 26.2, Varians (V) 85.4 dan Standar Deviasi (SD) 9.2. Sedangkan hasil pretes pada kelas kontrol adalah nilai tertinggi 43, nilai terendah 10, rata-rata 23, varian (V) 87.4, dan Standar Deviasi (SD) 9,3. Hasil postes pada kelas eksperimen adalah nilai tertinggi 92, nilai terendah 66, 
rata-rata 77,9, Varians (V) 59,9 dan Standar Deviasi (SD) 7,8. Sedangkan, hasil postes pada kelas kontrol adalah nilai tertinggi 77 , nilai terendah 38, rata-rata 58,5, Varians (V) 96,8 dan Standar Deviasi (SD) 7,8. Hasil ini menunjukkan bahwa kemampuan komunikasi awal kedua kelas tersebut sama. Hal ini digambarkan dari hasil pretes kelas kontrol maupun kelas eksperimen. Perbedaan kemampuan komunikasi terlihat jelas setelah diberi perlakuan, yang nampak pada hasil postes. Hal tersebut disajikan pada Tabel 3.

Tabel 3. Deskriptif Data Gain Kelas Eksperimen (E) dan Kelas Kontrol (K)

\begin{tabular}{cccccc}
\hline Kelas & Maks & Min & Rata-Rata & V & SD \\
\hline E & 0,91 & 0,33 & 0,70 & 0.01 & 0.10 \\
K & 0,72 & 0,25 & 0,45 & 0,02 & 0,12 \\
\hline
\end{tabular}

Data kelas eksperimen dan kelas kontrol menunjukkkan bahwa rata-rata gain yang diperoleh siswa kelas eksperimen sebesar 0,70 lebih tinggi dari rata-rata gain siswa kelas kontrol sebesar 0,45, maka secara deskriptif peningkatan kemampuan komunikasi matematika siswa kelas ekperimen lebih tinggi dari peningkatan kemampuan komunikasi matematika siswa kelas kontrol. Hal tersebut disajikan pada Tabel 4.

Tabel 4. Klasifikasi Gain Kelas Eksperimen (E) dan Kelas Kontrol (K)

\begin{tabular}{cccc}
\hline Kelas & Rentang Skor & Jumlah Siswa & Kategori \\
\hline $\mathrm{E}$ & $\mathrm{g} \geq 0,7$ & 21 & Tinggi \\
& $0,3 \geq \mathrm{g}>0,7$ & 20 & Sedang \\
& $\mathrm{g}<0,3$ & 0 & Rendah \\
$\mathrm{K}$ & $\mathrm{g} \geq 0,7$ & 1 & Tinggi \\
& $0,3 \geq \mathrm{g}>0,7$ & 36 & Sedang \\
& $\mathrm{g}<0,3$ & 5 & Rendah
\end{tabular}

Klasifikasi gain kelas eksperimen dan kelas kontrol menunjukkan bahwa siswa kelas eksperimen berada pada kategori gain tinggi dan sedang dan siswa kelas kontrol berada pada kategori tinggi, sedang dan rendah. Jumlah siswa yang memiliki gain tinggi pada kelas ekperimen sebanyak 51,2\%, sedangkan pada kelas kontrol hanya sebanyak 2,38\%. Siswa pada kelas kontrol paling banyak berada pada kategori sedang, yaitu sebanyak $85,7 \%$.

Sebelum melakukan pengujian hipotesis dengan uji-t, terlebih dahulu dilakukan pengujian terhadap sebaran normalitas data dan homogenitas varians dari pretes, postes, dan data gain yang diperoleh. Hasil uji normalitas disajikan pada Tabel 5. 
Tabel 5. Hasil Uji Normalitas Data Pretes-Postes dan Gain Kelas Eksperimen (E) dan Kontrol (K)

\begin{tabular}{ccccc}
\hline \multicolumn{5}{c}{ Data Gain } \\
\hline Kelas & $\mathrm{N}$ & $\chi_{\text {tabel }}^{2}$ & $\chi_{\text {hitung }}^{2}$ & Hasil \\
& \multicolumn{5}{c}{$\alpha=0,05$} & \\
$\mathrm{E}$ & 41 & 12.5916 & 3.3794 & Normal \\
$\mathrm{K}$ & 42 & 12.5916 & 12.2965 & Normal \\
\hline \multicolumn{5}{c}{ Data Pretes } \\
\hline Kelas & $\mathrm{N}$ & $\chi_{\text {tabel }}^{2}$ & $\chi_{\text {hitung }}^{2}$ & Hasil \\
& \multicolumn{5}{c}{$\alpha=0,05$} & 8.9200 & Normal \\
$\mathrm{E}$ & 41 & 12.5916 & 8.7120 & Normal \\
$\mathrm{K}$ & 42 & 12.5916 & Hasil \\
\hline \multicolumn{5}{c}{ Data Postes } \\
$\mathrm{Kelas}$ & $\mathrm{N}$ & $\chi_{\text {tabel }}^{2}$ & $\chi_{\text {hitung }}^{2}$ & Normal \\
& \multicolumn{5}{c}{$\alpha=0,05$} & 6.7496 & Normal \\
$\mathrm{E}$ & 41 & 12.5916 & 5.3231 & \\
$\mathrm{~K}$ & 42 & 12.5916 &
\end{tabular}

Hasil uji normalitas menunjukkan bahwa data pretes, postes, serta gain berdistribusi normal. Selanjutnya, data-data tersebut diuji homogenitasnya dengan menggunakan uji Fisher. Hasil pengujian menunjukkan bahwa ketiga data tersebut memiliki varians yang homogen. Data selengkapnya dapat dilihat pada Tabel 6.

Tabel 6. Hasil uji homogenitas data pretes, postes, dan gain kelas eksperimen (E) dan kelas Kontrol (K)

\begin{tabular}{|c|c|c|c|c|}
\hline \multicolumn{5}{|c|}{ Data gain } \\
\hline Kelas & $\mathrm{N}$ & $f_{\text {hitung }}$ & $f_{\text {tabel }}$ & Hasil \\
\hline $\mathrm{E}$ & 41 & 1.4 & 1.5 & Kedua varians sama \\
\hline K & 42 & & & atau homogen \\
\hline \multicolumn{5}{|c|}{ Data pretes } \\
\hline Kelas & $\mathrm{N}$ & $f_{\text {hitung }}$ & $f_{\text {tabel }}$ & Hasil \\
\hline E & 41 & 1.1 & 1.5 & Kedua varians sama \\
\hline K & 42 & & & atau homogen \\
\hline \multicolumn{5}{|c|}{ Data postes } \\
\hline Kelas & $\mathrm{N}$ & $f_{\text {hitung }}$ & $f_{\text {tabel }}$ & Hasil \\
\hline $\mathrm{E}$ & 41 & 1,5 & 1,5 & $\begin{array}{l}\text { Kedua varians sama } \\
\text { atau homogen }\end{array}$ \\
\hline
\end{tabular}

Berdasarkan hasil perhitungan uji normalitas dan uji homogenitas data gain skor ternormalisasi dari kelas eksperimen dan kelas kontrol menunjukkan bahwa data tersebut normal dan homogen. Karena semua asumsi sebagai prasyarat untuk melakukan uji- $t$ terpenuhi, maka dilanjutkan dengan uji hipotesis. 
Pengujian hipotesis yang pertama menggunakan uji one sample t. Hasil perhitungannya menunjukkan bahwa $t_{\text {hitung }}=10,84$. Setelah dibandingkan dengan $t_{\text {tabel }}=2,0195$, maka diperoleh $t_{\text {hitung }}>t_{\text {tabel }}$. Sehingga dapat disimpulkan penerapan langkah-langkah saintifik dengan pendekatan pemecahan masalah dalam setting pembelajaran tipe kooperatif tipe $N H T$ dikatakan efektif terhadap peningkatan kemampuan komunikasi matematika.

Pengujian hipotesis kedua menggunakan rumus $t$-test dengan polled varian dengan $d k=n_{1}+n_{2}-2$. Hasil perhitungannya menunjukkan bahwa $t_{\text {hitung }}=10,05$. Setelah dibandingkan dengan $t_{\text {tabel }}=1,9897$, maka diperoleh $t_{\text {hitung }}>t_{\text {tabel }}$. Sehingga dapat disimpulkan bahwa peningkatan kemampuan komunikasi matematika siswa dengan penerapan langkah-langkah saintifik dengan pendekatan pemecahan masalah dalam setting pembelajaran tipe kooperatif tipe NHT lebih tinggi dibandingkan dengan peningkatan kemampuan komunikasi matematika siswa dengan pemecahan masalah.

\section{SIMPULAN DAN SARAN}

Berdasarkan hasil dan pembahasan, maka dapat disimpulkan bahwa peningkatan kemampuan komunikasi matematika melalui penerapan pemecahan masalah dengan pendekatan saintifik dalam seting koperatif tipe NHT lebih tinggi dibandingkan dengan kemampuan komunikasi matematika siswa yang hanya menggunakan pendekatan pemecahan masalah.

Penerapan langkah-langkah saintifik dengan menggunakan model NHT memberikan dampak yang baik dalam proses maupun hasil pembelajaran, terutama kemampuan komunikasi matematika. Proses memecahkan masalah menjadi lebih terarah dan menghilangkan individualistis siswa dalam memecahkan masalah. Langkah-langkah santifik yang digunakan juga menuntun siswa secara perlahan dalam menguasai fakta, konsep, prinsip serta keterampilan dalam matematika, baik secara tertulis maupun secara lisan. Langkah-langkah ini pun mampu membuat siswa berpikir secara terstruktur dalam menyelesaikan sebuah masalah, dengan memanfaatkan notasi, istilah, lambang, rumus, diagram, tabel, grafik, dan model matematis secara benar. Kolaborasi dari pemecahan masalah, pendekatan saintifik serta NHT sebaiknya dilakukan dalam pembelajaran matematika dengan jumlah siswa yang relatif sedikit serta ketersediaan sarana dan prasarana yang cukup untuk mendukung proses pembelajaran. 


\section{DAFTAR RUJUKAN}

Ali, M. (2007). Ilmu dan Aplikasi Pendidikan. Bandung: PT. Imperial Bakti Utama.

Doerr, H. M. \& Lerman, S. (2009). Teachers Learning from Their Teaching: The Case of Communicative Practice (Learning Through Teaching mathematics). New York: Springer.

Huda, M. (2013). Model-Model Pengajaran dan Pembelajaran. Yogyakarta: Pustaka Belajar.

Izzati, N. \& Suryadi, D. (2010). Komunikasi Matematik dan PendidikanMatematika Realistik. Prosiding Seminar Nasional Matematika dan Pendidikan Matematika, 27 November 2010. Yogyakarta: FMIPA Universitas Negeri Yogyakarta.

Komara, A. O. (2015). Penerapan Model Pembelajaran Berbasis Masalah untuk Meningkatkan Kemampuan Komunikasi Matematis. In Seminar Nasional Matematika dan Pendidikan Matematika, 77-82, Yogyakarta: Universitas Negeri Yogyakarta

Kurnila, V. S. (2013). Kontribusi Standar Proses pada Kurikulum 2013 Guna Meningkatkan Kemampuan Algoritmik Siswa. Jurnal Pendidikan Dan Kebudayaan Missio, 10(1), 53-58.

Miftahurrohman \& Purnomo, E. A., (2017). Implementasi Model Pembelajaran Kombinasi Antara NHT dan TGT terhadap Kemampuan Komunikasi Matematis Siswa Kelas XI SMA Negeri 9 Semarang. Prosiding Seminar Nasional Pendidikan, Sains dan Teknologi FMIPA Universitas Muhammadiyah Semarang. Semarang: Universitas Muhammadiyah Semarang

Musfiqon, H. M. \& Nurdyansyah (2015). Pendekatan Pembelajaran Saintifik. Sidoarjo: Nizamia Learning Center.

Pehkonen, E., Näveri, L., \& Laine, A. (2013). On Teaching Problem Solving in School Mathematics $\mathrm{O}$ poučevanju reševanja problemov v šolski matematiki. C.E.P.S Journal, 3(4), 9-23.

Permendiknas Nomor 22 Tahun 2006 Tentang Standar Isi Mata Pelajaran Matematika (Salinan)

Permendikbud Nomor 65 Tahun 2013 Tentang Standar Proses Pendidikan Dasar dan Menengah (Salinan).

Sadiman. (2012). Media Pendidikan: pengertian, Pengembangan, dan Pemanfaatannya. Jakarta: Raja Grafindo Persada.

Sugiyono. (2012). Statistika untuk Penelitian. Bandung: Alfabeta. 
Sriraman, B. \& English, L. (2010). Theories of mathematics education. New York: Springer.

Susanto. (2013). Teori Belajar dan Pembelajaran di Sekolah Dasar. Jakarta: Kencana.

Susanto, A. S. \& Bharata, H. (2018). The effect of Cooperative Learning Model ThinkTalk-Write (TTW) Type on Mathematical Problem-Solving Abilities In Terms of Learning Habits. Al-Jabar: Jurnal Pendidikan Matematika, 9(1), 33-40.

Tinungki, G. M. (2015). The Role of Cooperative Learning Type Team Assisted Individualization to Improve the Students' Mathematics Communication Ability in the Subject of Probability Theory. Journal of Education and Practice, 6(32), 2731.

Rahmalia, Y., Armiati, \& Jazwinarti. (2012). Meningkatkan Kemampuan Komunikasi Matematis Siswa Melalui Penerapan Model Pembelajaran Kooperatif Teknik Numbered Head Together (NHT). Jurnal Pendidikan Matematika, 1(1), 52-58.

Yuwono, I. (2014). Pendidikan Matematika Dan Pendidikan Karakter Dalam Implementasi Kurikulum 2013. In Prosiding Seminar Nasional Pendidikan Matematika, Program Pascasarjana STKIP Siliwangi, Bandung (Vol. 15, pp. 1-3). 